\title{
EFFICIENCY OF CHEMICAL PESTICIDES TO CONTROL Spodoptera frugiperda AND VALIDATION OF PHEROMONE TRAP AS A PEST MANAGEMENT TOOL IN MAIZE CROP
}

\author{
IVAN CRUZ ${ }^{1}$, MARIA DE LOURDES CORRÊA FIGUEIREDOํ, RAFAEL BRAGA DA \\ SILVA $^{2}$ and JOHN E. FOSTER ${ }^{3}$
}

IEmbrapa Milho e Sorgo, CEP: 35701-970, Sete Lagoas, MG, Brasil, E-mail: ivancruz@cnpms. embrapa.br,figueiredomlc@yahoo.com.br

${ }^{2}$ Universidade Federal de São Carlos (UFSCar), CEP: 13565-905, São Carlos, SP, Brasil, E-mail: rafaelentomologia@yahoo.com.br

${ }^{3}$ University of Nebraska-Lincoln, Department of Entomology, Insect Genetics Laboratory, Lincoln, NE 68583-0816,USA, E-mail: jfoster1@unl.edu

Revista Brasileira de Milho e Sorgo, v.9, n.2, p.107-122, 2010

\begin{abstract}
The fall armyworm, Spodoptera frugiperda (J. E. Smith) (Lepidoptera: Noctuidae) is a key pest of maize (Zea mays L.) crop, and invariably demand control measures. However, the time of insecticide application has not been properly defined, leading to an inefficiency in the control and, therefore, without getting the maximum from the treatment procedure. Many times the pest has been reaching population density that would demand control measure very early in the season. To detect such populations and, therefore, to decide about the time of the insecticide application, the experiment was conducted installing soon after the plant emergency, a delta type Pherocon 1C trap with a commercial synthetic sexual pheromone (Bio spodoptera ${ }^{\circledR}$ Chem Tica International, S.A.). Insecticide first application was made ten days after the capture of three adults per trap/ha. A second application was accomplished when was again captured a minimum of three moths, but initiating the counting four-days after the previous insecticide application. This same procedure was adopted for a third application. The evaluated insecticides provided a significant reduction in the infestation level, for variable periods, depending on the chemical suggesting that the pheromone trap can be a useful tool in integrated pest management program in maize crop in Brazil.
\end{abstract}

Key words: fall armyworm, integrated pest management, economic injury level, chemical control. 


\section{EFICIÊNCIA DE INSETICIDAS NO CONTROLE DE Spodoptera frugiperda E VALIDAÇÃO DE ARMADILHA DE FEROMÔNIO COMO FERRAMENTA DE MANEJO DA PRAGA NA CULTURA DO MILHO}

RESUMO - A lagarta-do-cartucho, Spodoptera frugiperda (J. E. Smith) (Lepidoptera: Noctuidae), é uma praga chave da cultura do milho (Zea mays L.), demandando invariavelmente medidas de controle. No entanto, a época de aplicação de inseticidas não tem sido propriamente definida, ocasionando, muitas vezes, a ineficiência do controle e, portanto, sem obter o aproveitamento máximo da medida utilizada. A praga tem atingido, em alguns casos, populações que exigem medidas de controle logo após a emergência da planta. Para detectar tais populações e, portanto, decidir sobre a época mais adequada para a aplicação de inseticidas, foi utilizada, logo após a emergência da planta, uma armadilha tipo delta, Ferocon 1C, contendo feromônio sexual sintético da praga (Bio spodoptera ${ }^{\circledR}$ Chem Tica Internacional, S.A.). O experimento foi conduzido em delineamento de blocos ao acaso, com cinco tratamentos e oito repetições. A pulverização dos inseticidas foi realizada dez dias após a captura de três mariposas da praga por armadilha/ha. Uma segunda aplicação foi realizada quando novamente foi coletado o mínimo de três mariposas, em contagens consideradas quatro dias após a aplicação anterior dos inseticidas. Esse mesmo procedimento foi adotado para uma terceira aplicação. Os inseticidas avaliados proporcionaram redução significativa no nível de infestação, por períodos variáveis, dependendo do produto químico, sugerindo que a armadilha de feromônio pode ser uma ferramenta útil em programa de manejo integrado da praga na cultura do milho, no Brasil. Palavras-chave: lagarta-do-cartucho, manejo integrado de pragas, nível de dano econômico, controle químico.

The fall armyworm, Spodoptera frugiperda (J. E. Smith) (Lepidoptera: Noctuidae) is a major pest of maize (Zea mays L.) in the Americas (Cruz \& Turpin, 1982, 1983; Cruz et al., 1996, 1999; Figueiredo et al., 2006). In Brazil, this pest causes serious economic damage, estimated at more than 400 million dollars annually (Cruz, 2008). The importance of the pest has increased due to selection of insect populations resistant to chemical insecticides (Cruz, 2002). The 
management of $S$. frugiperda, when adopted, is still based on spraying with insecticides and generally not considering the economic threshold (Cruz, 1995). Costa et al. (2005) in order to determine the best control of $S$. frugiperda in maize and sorghum [Sorghum bicolor (L.) Moench] in lowland region and to evaluate the response of crops on grain yield, performed two applications of pesticides, the first being held 19 days after plant emergence (DAE), when maize and sorghum were in vegetative stage V4 and E1 (four fully expanded leaves), respectively, and the second at $47 \mathrm{DAE}$, without determining the actual pest infestation.

Albuquerque et al. (2006) evaluated the effectiveness of controlling fall armyworm, applying pesticides eight days after plant emergence (DAE), when the incidence of $20 \%$ of plants exhibiting pin hole type damage or 12 DAE, when leaves were shown to be scraped and perforated. Tomquelski et al. (2007) in an experimental series performed, in a first experiment, two applications of insecticides, the first 15 days after maize emergence (DAE) and the second seven days later, based on the efficiency of products, considering reapplying for those less effective. The same authors also evaluated a second control alternative applying insecticides according to plant growth stage and later assessing the developmental stage of caterpillars. Therefore, it is clear that there is a gap regarding the definition of spray timing to control the fall armyworm in maize crop. However, decision on pest control should depend on the level of infestation, control cost and production monetary value. Greater economical value of crop and lower cost of control measures led to the decision to a lower level of pest infestation. This level has been determined by sampling the apparent number of infested plants. Many times that number may be under or overestimated depending on the time when sampling occurs (Cruz, 2007). Therefore, to improve the accuracy of the decision to use control measures will be necessary to determine, as early as possible, the time that the insect arrived in the target area and, preferably, the detection of a pest stage before any damage. Currently this is possible through the use of synthetic pheromone traps to monitor the presence of the moth. Kit containing synthetic pheromone trap is marketed in the various country including Brazil. According to manufacturer the trap is used at a density of one to five hectares. Based on biological data (Cruz \& Turpin, 1983) and on the level of technology used in corn production, the decision point for the use of control measures with chemical insecticide could be achieved by a minimum of three moths captured per trap per hectare, on average. The knowledge about the pest biology (Cruz, 1995) shows that from moth oviposition until ten days after, the caterpillar will be between the third and fourth instar, and have no potential to cause irreversible damage. At that 
stage, the caterpillars are still very susceptible to insecticides (Cruz, 2007). Also, within the period considered, eggs and small larvae can be eliminated by the major natural enemies, sometimes avoiding the needs for chemicals (Cruz, 2007). Taking these assumptions into consideration, application of insecticide should not be immediate, but ten days after the capture of three or more moths per trap.

The use of pheromone traps as a strategy for monitoring adult $S$. frugiperda will be useful to indicate the real demand for control of the fall armyworm in maize, especially when the trap is placed in field soon after planting. If placed a few days before planting the data regarding insect capture may also support the decision on the use of seed treatment with appropriate chemical insecticide. Thus, the aim of this study was to evaluate the efficiency of different chemical insecticides to control the fall armyworm and validate the technology of pheromone trap as a useful tool in integrated pest management program in maize crop.

\section{Material and Methods}

The experiment was conducted in a randomized complete block design with five treatments and eight replications. Each plot consisted of ten 10-meters long rows (500 plants) using the hybrid BRS 1030. Before planting maize, the area was desiccated with glyphosate at a dose of three $1 /$ ha. Soon after plant emergence a delta-type trap, Pherocon 1C, was installed in the center of the experimental area (1 ha), containing sex pheromone of $S$. frugiperda (Bio spodoptera $^{\circledR}$ Chem Tica International, S.A.). According to assumption, a cumulative number of three adults (threshold) caught per trap would be enough to produce larvae to cause infestation at least in $10 \%$ of the plants, and provoke significant economic damage if control measures were not taken. However, insecticide application should be made only ten days after the threshold level. Before this period the caterpillars are too young to cause significant damage to the plant and susceptible to the action of different species of natural enemies, as pointed out by Cruz (1995, 2007). A new insecticide application also follows the same pattern, i.e., after the capture of three moths. However, starting the count of the number of insects trapped four days after the last insecticide application (assuming this interval, the average residual effect of the applied product).

The treatments were: control (plot without insecticide application), LannateBR(methomyl), $600 \mathrm{ml} / \mathrm{ha}$; Fury 200 EW (zetacypermethrin), $90 \mathrm{ml} / \mathrm{ha}$; EC Match (lufenuron), $300 \mathrm{ml} / \mathrm{ha}$ and Tracer (spinosad), $50 \mathrm{ml} / \mathrm{ha}$. Insecticides were applied using a $\mathrm{CO}_{2}$ pressurized backpack sprayer, 80.04 beak, with a flow of 295 1/ ha. The day preceding the first spray within each plot, ten plants were collected at random 
and evaluated in the laboratory computing the number of alive and dead larvae. Alive larvae were visually classified according to size, in classes meaning less than $0.5 \mathrm{~cm}$, between 0.5 and $1.0 \mathrm{~cm}$, between 1.0 and $1.5 \mathrm{~cm}$, and so on. Larvae were kept individually in $50 \mathrm{ml}$ cups containing artificial diet of $S$. frugiperda (Cruz, 2009) to determine the presence of parasitoids. Similar samples and using the same methodology continued to be held at a frequency of twice a week. The results were submitted to Analysis of Variance (ANOVA) and means separated by Duncan test $(\mathrm{p} \leq 0.05)$ using the statistical program MSTAT-C, version 2.1 (Russel, 1989). When necessary, data were transformed into square root of the variable.

\section{Results and Discussion}

The pre-set economic injury level (three moths/trap) was reached four days after installation of the trap. The first insecticide application occurred 14 days after plant emergence. The second spraying took place on August 28 and the third on September 14 , or 39 and 56 days after plant emergence, respectively. In general, the population of males captured over time, although growing, showed no major peaks (Figure 1).

Overall plant infestation in evaluation performed the day before the first spray was 28.5, on average (Table 1). Four days after spraying, there was a significant reduction in infestation, particularly in plots that received the insecticides spinosad, methomyl, and zetacypermethrin with infestation level averaging $2.5 \%$. The effect of lufenuron was not observed and the infestation level (22.5\%) was higher than the level obtained before application (17.5\%). However, the infestation level was significantly lower than the level found in control plots (43.7\%).

Six days after spraying, the percentage of infested plants was significantly lower in all treated plots compared to check ones (Table 1). However, the infestation level in lufenuron plots was above $10 \%$ (Table 1 ) and significantly different from the average recorded in methomyl $(6.2 \%)$ or zetacypermethrin plots $(8.7 \%)$. On spinosad plots the infestation level was only $1.2 \%$. Eleven days after spraying, there was a level off in the infestation level among treated plots averaging 7.8\% (5.0-10.0) and a better performance of the lufenuron (Table 1). The infestation level in untreated plots was $25 \%$.

Evaluation made 13 days after spraying indicated no more effect of zetacypermethrin once the average infestation level of $26.2 \%$ was similar to the average of $16.2 \%$ recorded in untreated plots. No significant difference was observed among the other treatments, with an average infestation level of $7.1 \%$. Further evaluations indicated no more residual effect of all insecticide (Table 1). 


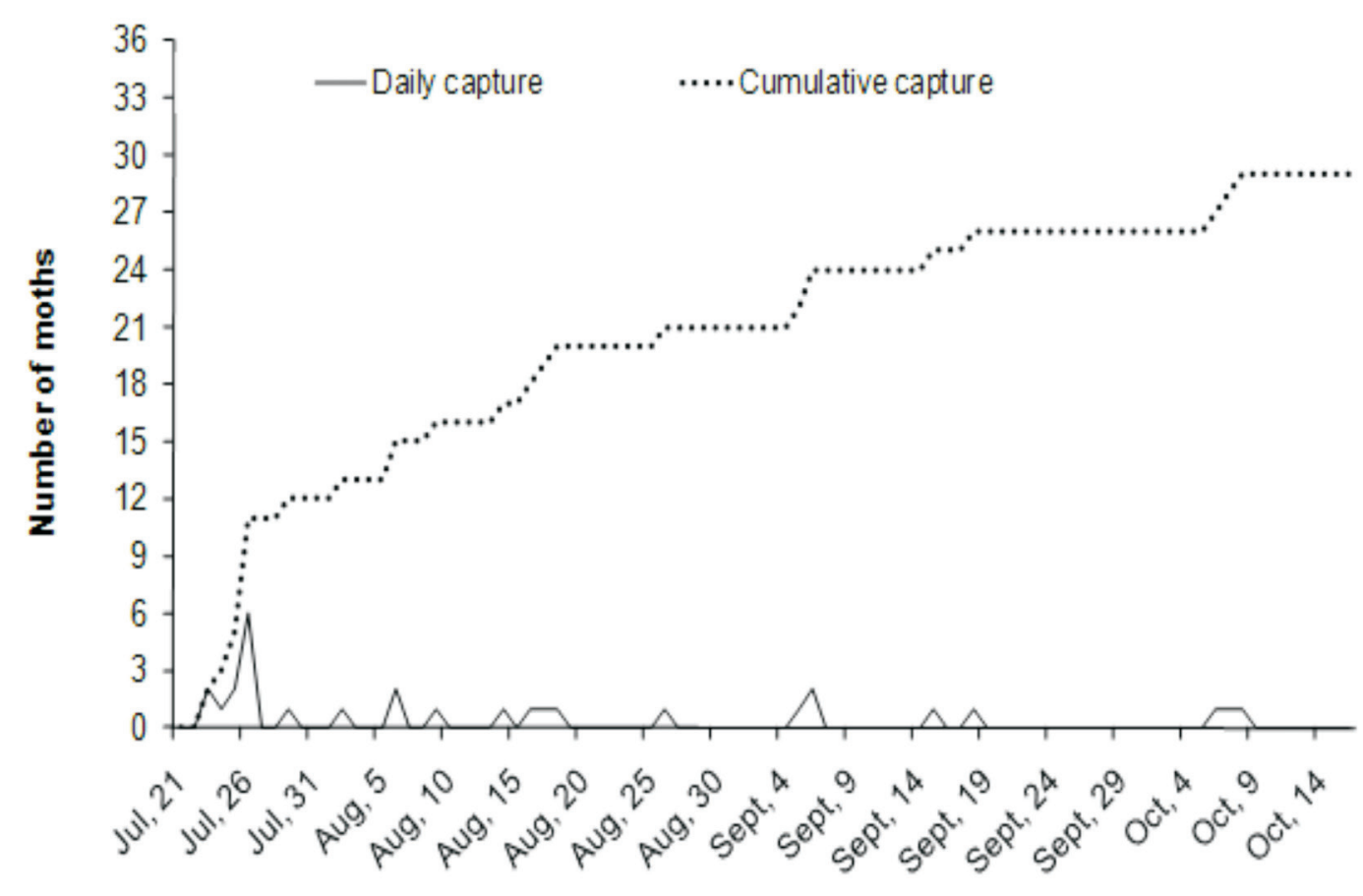

Date

FIGURE 1. Number of male Spodoptera frugiperda (J. E. Smith) (Lepidoptera: Noctuidae) caught in traps containing synthetic sex pheromone in Sete Lagoas, Minas Gerais State, Brazil, 2008.

Evaluations made after the second the other hand, in zetacypermethrin plots the insecticide application (Table 2), indicated a infestation level was between 10 and $18.7 \%$.

significant infestation reduction in lufenuron Four days after the third and final and spinosad plots compared to almost all other treatments including the untreated plots. Methomyl provided a good insect control up to 11 days after application with infestation level between 2.5 and $7.5 \%$. For the same period, on insecticide application, in the untreated plots infestation level was $36.2 \%$ and significantly higher than any other mean, except for that found in the zetacypermethrin plots (Table 3). The insecticide methomyl provided quick 


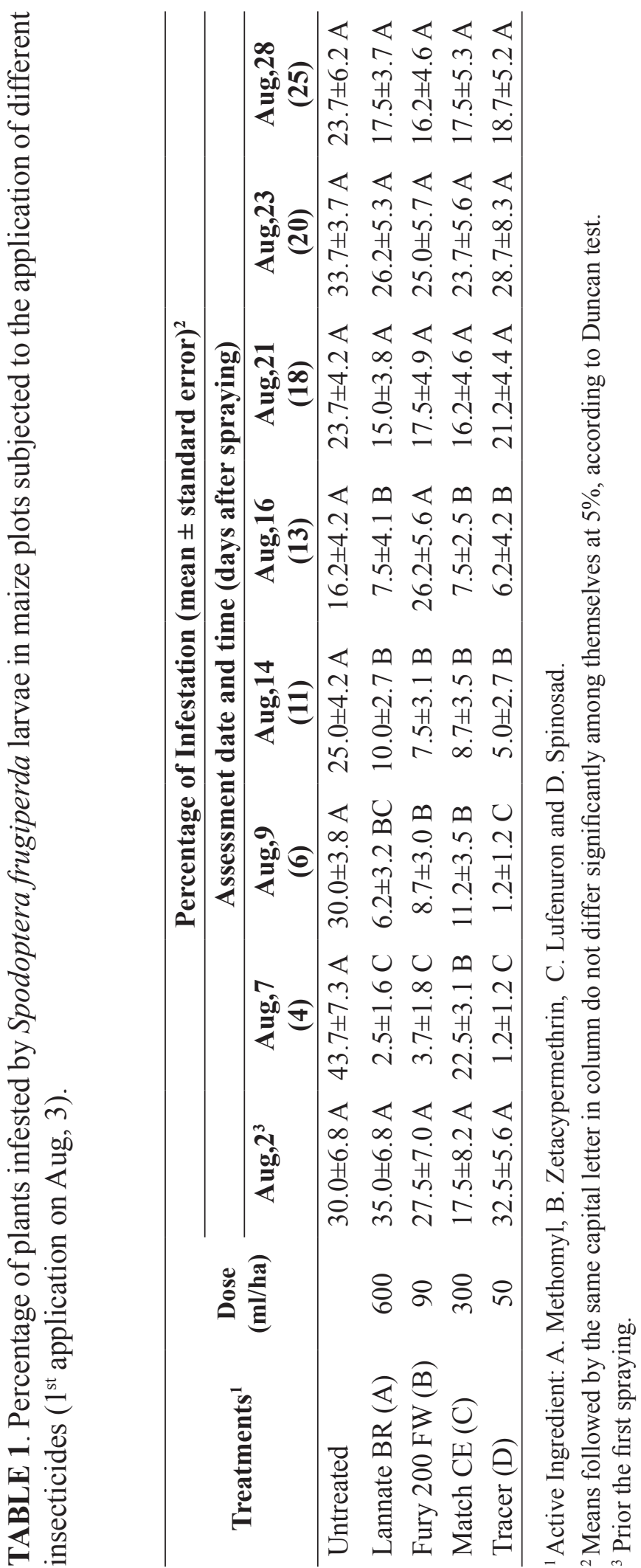

Revista Brasileira de Milho e Sorgo, v.9, n.2, p.107-122, 2010
Versão impressa ISSN 1676-689X / Versão on line ISSN 1980-6477 - http://www.abms.org.br 


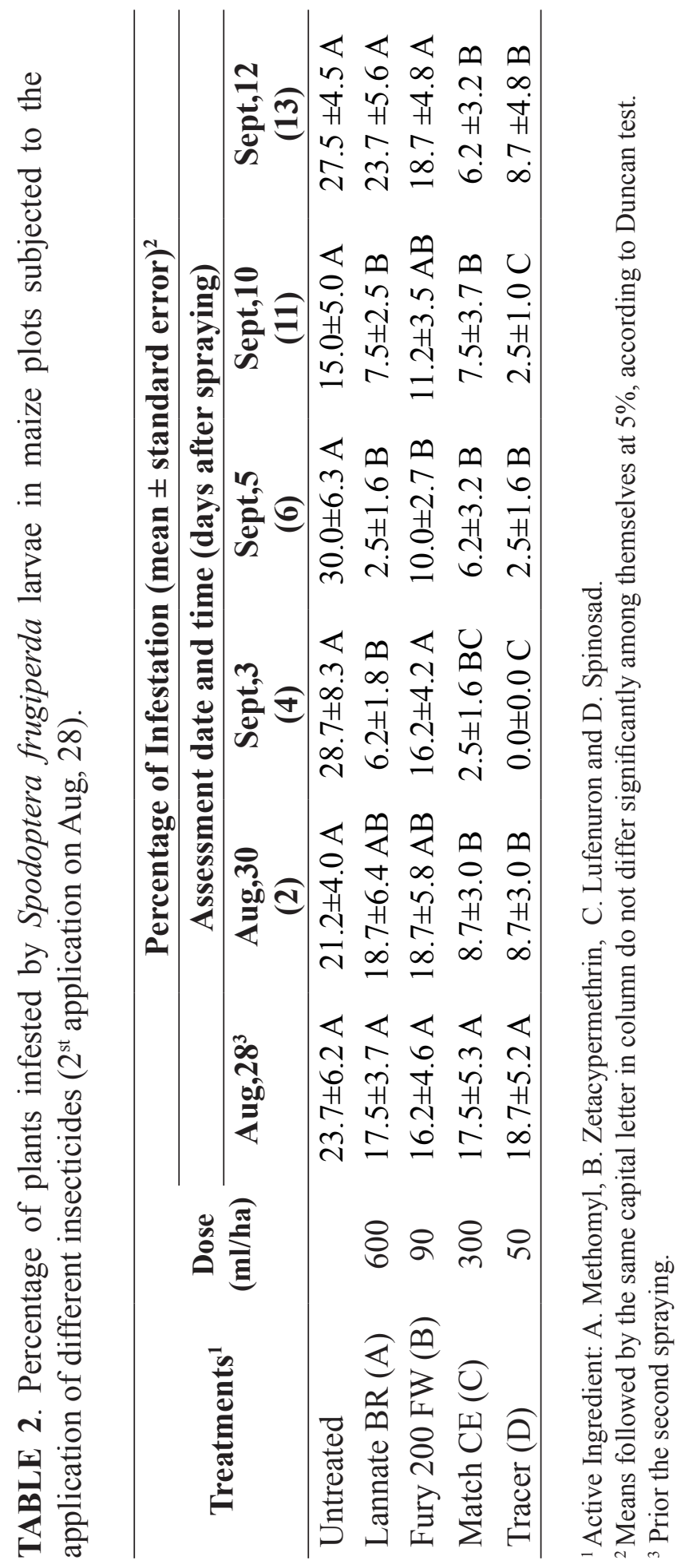




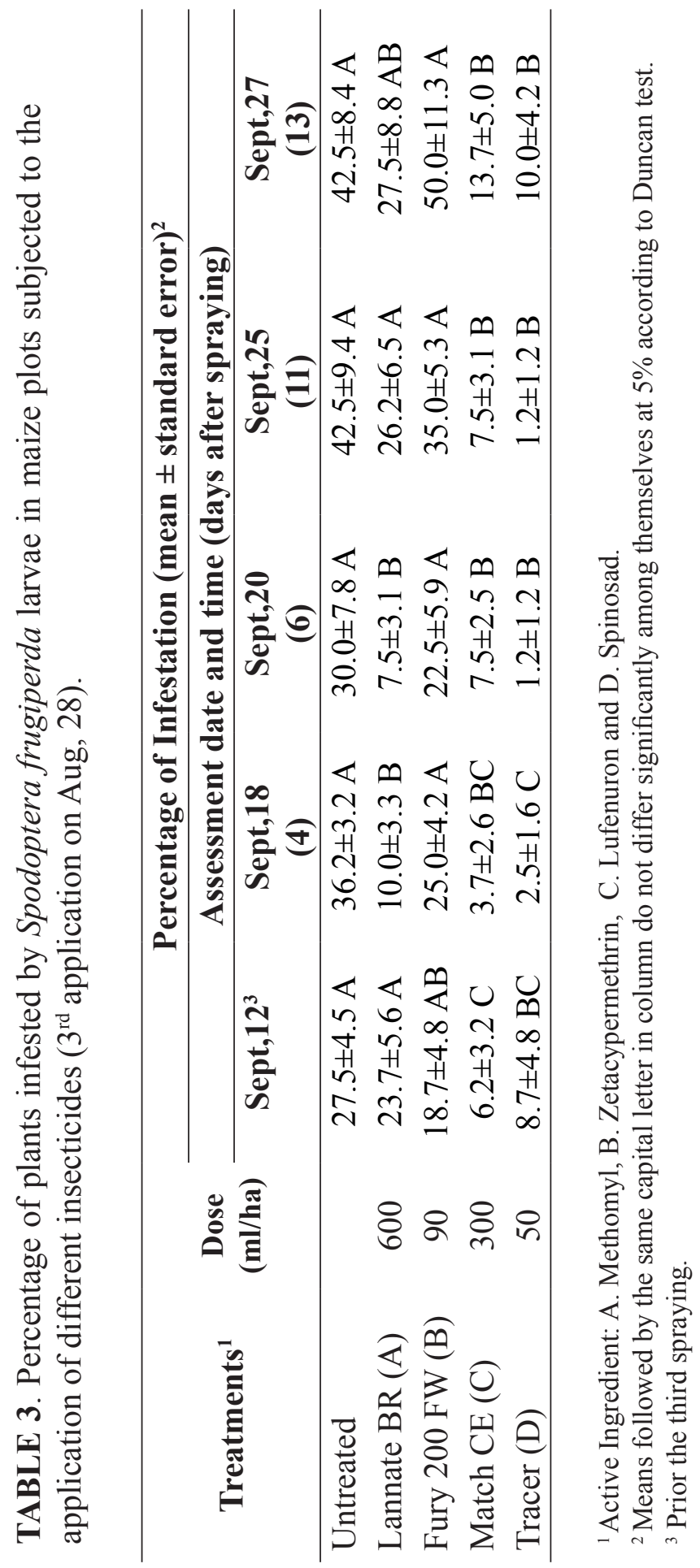


response, reducing the pest infestation from 23.7 to $10 \%$. Significant infestation reduction was also found in lufenuron and spinosad plots with no significant difference between the two treatment means, respectively, 3.7 and 2.5\%. Six and 11 days after the application the infestation level in plots with these two insecticides was 7.5 and $1.2 \%$, respectively. In methomyl plots infestation was 7.5 and $26.2 \%$ whereas in the zetacypermethrin plots the infestation level was 22.5 and $35 \%$. In the last evaluation made 13 days after insecticide application, only in spinosad plots infestation was lower $(10 \%)$ compared to the other treatments (Table 3).

The distribution of larvae by size during different sampling periods (Table 4) in plots without insecticide application indicated that until 17 days after the first moth captured on trap most larvae measured about 0.5 centimeter long. One week later, caterpillars of the same size accounted for only $28.6 \%$.

TABLE 4. Frequency of occurrence of different sizes of Spodoptera frugiperda larvae in maize (Zea mays L.) plants without application of chemical insecticides.

\begin{tabular}{|c|c|c|c|c|c|c|c|c|c|}
\hline \multirow{2}{*}{$\begin{array}{l}\text { Assessment } \\
\text { time }\end{array}$} & \multirow{2}{*}{$\begin{array}{l}\text { Days after the first } \\
\text { capture of adults in } \\
\text { pheromone trap }\end{array}$} & \multirow{2}{*}{$\mathbf{N}$} & \multicolumn{7}{|c|}{ Distribution (\%) by size class $(\mathrm{cm})$ larvae } \\
\hline & & & 0.5 & 1.0 & 1.5 & 2.0 & 2.5 & 3.0 & 3.5 \\
\hline Aug, 02 & 10 & 38 & 100 & & & & & & \\
\hline Aug, 07 & 15 & 57 & 100 & & & & & & \\
\hline Aug, 09 & 17 & 30 & 96.7 & 3.3 & & & & & \\
\hline Aug, 16 & 24 & 14 & 28.6 & 42.9 & 28.6 & & & & \\
\hline Aug, 21 & 29 & 27 & 55.6 & 22.2 & 11.1 & 7.4 & 0.0 & 3.7 & \\
\hline Aug, 23 & 31 & 29 & 51.7 & 13.8 & 34.5 & & & & \\
\hline Aug, 28 & 36 & 19 & 36.8 & 10.5 & 31.6 & 21.1 & & & \\
\hline Aug, 30 & 38 & 21 & 76.2 & 14.3 & 9.5 & & & & \\
\hline Sept, 03 & 41 & 26 & 42.3 & 34.6 & 19.2 & 3.8 & & & \\
\hline Sept, 05 & 43 & 21 & 57.1 & 38.1 & 4.8 & & & & \\
\hline Sept, 10 & 48 & 14 & 57.1 & 21.4 & 14.3 & 7.1 & & & \\
\hline Sept, 12 & 50 & 22 & 63.6 & 22.7 & 13.6 & & & & \\
\hline Sept, 14 & 52 & 40 & 47.5 & 30.0 & 22.5 & & & & \\
\hline Sept, 20 & 58 & 28 & 60.7 & 32.1 & 7.1 & & & & \\
\hline Sept, 25 & 63 & 39 & 20.5 & 38.5 & 25.6 & 7.7 & 2.6 & 5.1 & \\
\hline Sept, 27 & 65 & 42 & 7.1 & 26.2 & 21.4 & 14.3 & 16.7 & 9.5 & 4.8 \\
\hline
\end{tabular}


This percentage increased again in the following periods of sampling, with a mean of $54.9 \%$ in the assessment at 58 days after the beginning of the capture of moths in the trap. These data corroborate the expectation considering the flow of moths in the area, measured by the trap (Figure 1).

The results of the frequency distribution of fall armyworm larva size in evaluation made just before chemical spraying (Table 5) indicate that by the time of the first application all larvae were of $0.5 \mathrm{~mm}$ long.

By the time of the second spray in untreated plots, larvae of at most one centimeter long represented $47.3 \%$ of the sample. The frequency of larvae between one and $1.5 \mathrm{~cm}$ was $31.6 \%$. In methomyl, zetacypermethrin and spinosad plots larvae up to $0.5 \mathrm{~cm}$, comprises $62.5,55.6$ and $65.2 \%$, respectively, indicating a re-infestation. In the case of the lufenuron

TABLE 5. Distribution of frequency of occurrence of different sizes of Spodoptera frugiperda larvae in maize, immediately before spraying with insecticides.

\begin{tabular}{|c|c|c|c|c|c|c|c|c|c|}
\hline \multirow{2}{*}{$\begin{array}{c}\text { Number of } \\
\text { spraying/ } \\
\text { date }\end{array}$} & \multirow{2}{*}{ Treatments } & \multirow{2}{*}{ Active ingredient } & \multicolumn{7}{|c|}{ Distribution (\%) by size class (cm) of larvae } \\
\hline & & & 0.5 & 1.0 & 1.5 & 2.0 & 2.5 & $\mathbf{3 . 0}$ & 3.5 \\
\hline 1 & Untreated & & 100 & & & & & & \\
\hline \multirow[t]{4}{*}{$($ Aug/3) } & Lannate BR & Methomyl & 100 & & & & & & \\
\hline & Fury $200 \mathrm{EW}$ & Zetacypermethrin & 100 & & & & & & \\
\hline & Match CE & Lufenuron & 100 & & & & & & \\
\hline & Tracer & Spinosad & 100 & & & & & & \\
\hline 2 & Untreated & & 36.8 & 10.5 & 31.6 & 21.1 & & & \\
\hline \multirow[t]{4}{*}{$($ Aug/28) } & Lannate BR & Methomyl & 62.5 & 18.8 & 12.5 & 6.3 & & & \\
\hline & Fury 200 EW & Zetacypermethrin & 55.6 & 27.8 & 16.7 & 0.0 & & & \\
\hline & Match CE & Lufenuron & 26.7 & 20.0 & 46.7 & 6.7 & & & \\
\hline & Tracer & Spinosad & 65.2 & 21.7 & 8.7 & 4.3 & & & \\
\hline \multirow{5}{*}{$\begin{array}{c}3 \\
(\text { Sept/12) }\end{array}$} & Untreated & & 63.6 & 22.7 & & & & & \\
\hline & Lannate BR & Methomyl & 86.4 & 13.6 & & & & & \\
\hline & Fury 200 EW & Zetacypermethrin & 78.3 & 21.7 & & & & & \\
\hline & Match CE & Lufenuron & 86.7 & 13.3 & & & & & \\
\hline & Tracer & Spinosad & 100.0 & & & & & & \\
\hline
\end{tabular}


plots, due to its slower action, $53.4 \%$ of larvae were higher than $1.5 \mathrm{~cm}$ long. In the third and last spraying time, the insects found were mainly from re-infestation, once the frequency of small larvae (maximum of $0.5 \mathrm{~cm}$ ) represented $63.6 \%$ of all sample.

\section{Occurrence of parasitoids}

Prior to the first insecticide application, natural larval parasitism was $36.42 \%$ (Table 6). In the laboratory $50.57 \%$ of the collected larvae became moths. Of the remaining, $13.0 \%$ died of undetermined causes, which could be at least partly due to parasitoids. Among the parasitoids the predominant species was Chelonus insularis Cresson (Hymenoptera: Braconidae), which lay eggs inside egg and emerges from larva host (Rezende et al., 1995). Eiphosoma laphygmae Costa Lima (Hymenoptera: Ichneumonidae), a larval parasitoid, was also important. Together these two parasitoids contributed with 17.6 and $14.35 \%$ of total parasitism (Table 6 ).

From 1292 larvae collected after insecticide application $35.6 \%$ was collected in untreated plots. On these plots, $58.7 \%$ of larvae became adults of S. frugiperda, 27.39\% were parasitized and $13.91 \%$ died without apparent cause (Table 7).

In insecticide plots the percentage of moths obtained was also close to that found in the untreated plots, with averages ranging between 53.61 and $60.71 \%$. Parasitism ranged between 17.86 and $29.81 \%$, close to that obtained in untreated plots (Table 7). Again there was a predominance of the parasitoids $C$. insularis and E. laphygmae, which along with the species Campoletis flavicincta (Ashmead) (Hymenoptera: Ichneumonidae) accounted for about $24 \%$ mortality.

\section{Conclusion}

The efficiency of insecticides used to control the fall armyworm in maize crop, when the spraying decision was based on the capture of moths in pheromone baited traps was high, which does not always occur when other methods of monitoring are adopted; therefore, other characteristics such as cost and environmental impact could be considered in choosing a product.

\section{Acknowledgments}

To "Conselho Nacional de Desenvolvimento Científico e Tecnológico (CNPq)" and "Fundação de Apoio à Pesquisa do Estado de Minas Gerais (FAPEMIG)" for Grant and financial funds. 


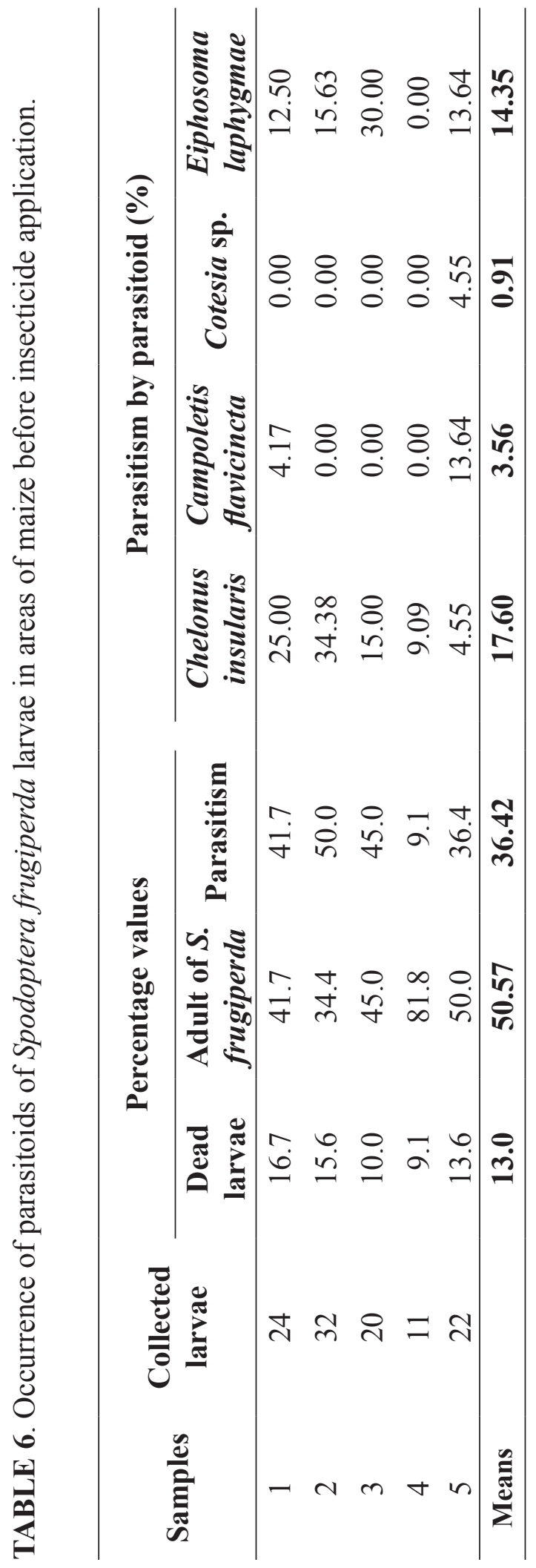




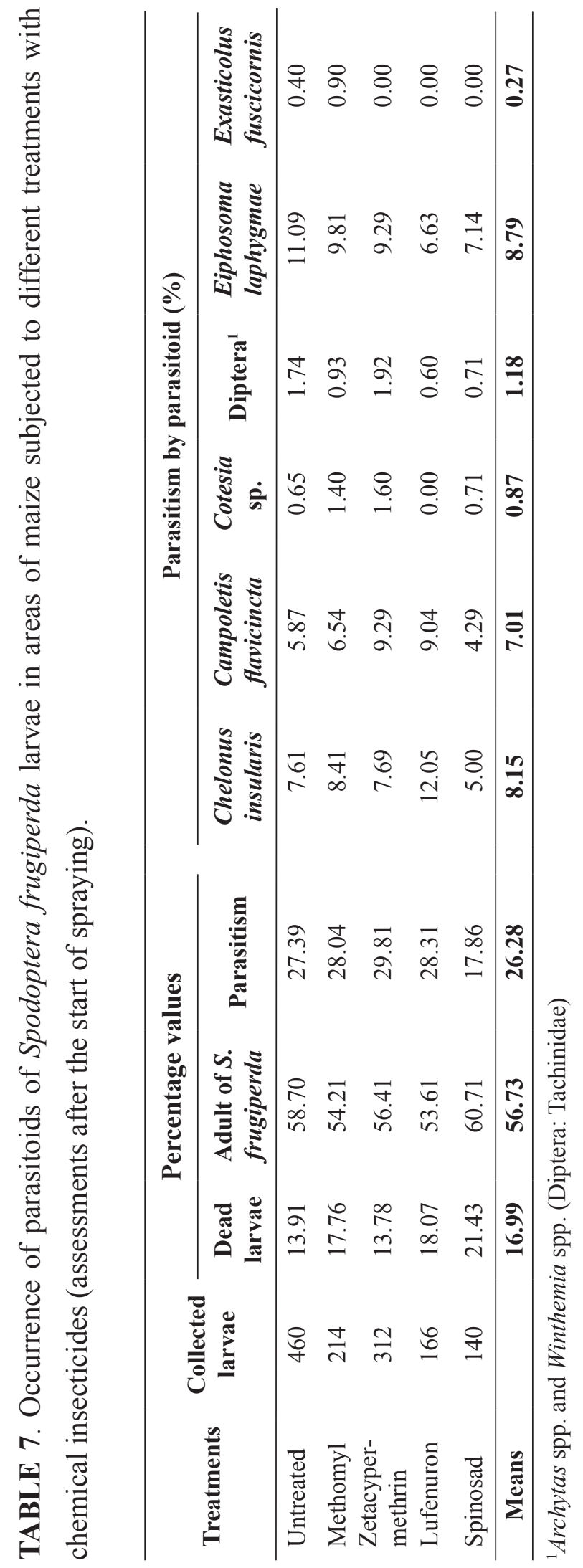




\section{Literature Cited}

ALBUQUERQUE, F. A.; BORGES, L. M.; IACONO, T. O.; CRUBELATI, N. C. S.; SINGER, A. C. Eficiência de inseticidas aplicados em tratamento de sementes e em pulverização, no controle de pragas iniciais do milho. Revista Brasileira de Milho e Sorgo, Sete Lagoas, v. 5, n. 1, p. 15-25, 2006.

COSTA, M. A. G.; GRUTZMACHER, A. D.; MARTINS, J. F. S.; COSTA, E. C.; STORCH, G., STEFANELLO JÚNIOR, G. J. Eficácia de diferentes inseticidas e de volumes de calda no controle de Spodoptera frugiperda nas culturas do milho e sorgo cultivados em várzea. Ciência Rural, Santa Maria, v. 35, n. 6, p. 1234-1242, 2005.

CRUZ, I. Métodos de criação de agentes entomófagos de Spodoptera frugiperda (J. E. Smith), p. 111-135. In: BUENO, V. H. P. (Ed.). Controle biológico de pragas: produção massal e controle de qualidade. Lavras: UFLA, 430p. 2009.

CRUZ, I. Manejo de pragas, p. 303-362. In: CRUZ, J. C.; KARAM, D.; MONTEIRO, M.A.; MAGALHÃES, P. C. (Ed). A cultura do milho. Brasília: Embrapa Informação Tecnológica. p. 303-362. 2008.

CRUZ, I. Alternativas para o controle da lagartado-cartucho, Spodoptera frugiperda e principais cuidados no uso de milhos transgênicos resistentes a insetos. In: FANCELLI, A. L.; DOURADO NETO, D. (Ed.). Milho - Fatores determinantes da produtividade. Piracicaba: USP-ESALQ, 2007.
CRUZ, I. Manejo da resistência de insetos pragas a inseticidas com ênfase em Spodoptera frugiperda (Smith). Sete Lagoas: Embrapa Milho e Sorgo, 2002. 15p. (Embrapa Milho e Sorgo. Documentos, 21).

CRUZ, I.; FIGUEIREDO, M. L. C.; OLIVEIRA, A. C.; VASCONCELOS, C. A. Damage of Spodoptera frugiperda (Smith) in different maize genotypes cultivated in soil under three levels of aluminium saturation. International Journal of Pest Management, London, v. 45, p. 293-296, 1999.

CRUZ, I.; OLIVEIRA, L. J.; VASCONCELOS, C. A. Efeito do nível de saturação de alumínio em solo ácido sobre os danos de Spodoptera frugiperda (J. E. Smith) em milho. Anais da Sociedade Entomológica do Brasil, Jaboticabal, v. 25, p. 293-297, 1996.

CRUZ, I. A lagarta-do-cartucho na cultura do milho. Sete Lagoas: Embrapa-CNPMS, 1995. 45p. (Embrapa-CNPMS. Circular Técnica, 21).

CRUZ, I.; TURPIN, F. T. Efeito da Spodoptera frugiperda em diferentes estádios de crescimento da cultura de milho. Pesquisa Agropecuária Brasileira, Brasília, DF, v. 17, n. 3, p. 355-359, 1982.

CRUZ, I.; TURPIN, F. T. Yield impact of larval infestation of the fall armyworm Spodoptera frugiperda (J. E. Smith) to mid-whorl growth stage of corn. Journal of Economic 
Entomology, College Park, v. 76, p. 10521054, 1983.

FIGUEIREDO, M. L. C.; MARTINS-DIAS, A. M. P.; CRUZ, I. Relação entre a lagarta do cartucho e seus agentes de controle biológico natural na produção de milho. Pesquisa Agropecuária Brasileira, Brasília, DF, v. 41, n. 12, p. 1693-1698, 2006.

REZENDE, M. A. A.; CRUZ, I.; DELLA LUCIA, T. M. C. Aspectos biológicos do parasitóide Chelonus insularis (Cresson) (Hymenoptera, Braconidae) criados em ovos de Spodoptera frugiperda (Smith) (Lepidoptera,
Noctuidae). Revista Brasileira de Zoologia, Curitiba, v. 12, n. 4, p. 779-784, 1995.

RUSSEL, D. F. MSTAT-C Statistical Package Program ver. 2.1 Michigan State University, 1989.

TOMQUELSKI, G. V.; MARTINS, G. L. M. Eficiência de inseticidas sobre Spodoptera frugiperda (J. E. Smith, 1797) (Lepidoptera: Noctuidae) em milho na região dos chapadões. Revista Brasileira de Milho e Sorgo, Sete Lagoas, v. 6, n. 1, p. 26-39, 2007. 